\title{
\$ms
}

\section{Production, purification, and characterization of a novel cold-active superoxide dismutase from the Antarctic strain Aspergillus glaucus 363}

\author{
Radoslav ABRASHEV ${ }^{a}$, Georges FELLER ${ }^{b}$, Nedelina KOSTADINOVA ${ }^{a}$, \\ Ekaterina KRUMOVA ${ }^{a}$, Zlatka ALEXIEVA ${ }^{a}$, Maria GERGINOVA ${ }^{a}$, \\ Boryana SPASOVA ${ }^{a}$, Jeni MITEVA-STALEVA ${ }^{a}$, Spassen VASSILEV ${ }^{a}$, \\ Maria ANGELOVA ${ }^{a, *}$ \\ ${ }^{a}$ The Stephan Angeloff Institute of Microbiology, Bulgarian Academy of Sciences, Academician G. Bonchev 26, 1113 \\ Sofia, Bulgaria \\ ${ }^{\mathrm{b}}$ Laboratory of Biochemistry, Centre for Protein Engineering, University of Liège, B-4000 Liège, Belgium
}

\section{A R T I C L E I N F O}

\section{Article history:}

Received 19 January 2016

Received in revised form

29 February 2016

Accepted 4 March 2016

Available online 11 March 2016

Corresponding Editor:

Simon V. Avery

Keywords:

Antarctic fungi

Biosynthesis

Cold-active SOD

$\mathrm{Cu} / \mathrm{Zn}$-SOD gene sequence

Enzyme characterization

\begin{abstract}
A B S T R A C T
The Antarctic fungal strain Aspergillus glaucus 363 produces cold-active (CA) Cu/Znsuperoxide dismutase (SOD). The strain contains at least one gene encoding $\mathrm{Cu} / \mathrm{Zn}$-SOD that exhibited high homology with the corresponding gene of other Aspergillus species. To our knowledge, this is the first nucleotide sequence of a CA Cu/Zn-SOD gene in fungi. An effective laboratory technology for A. glaucus SOD production in $3 \mathrm{~L}$ bioreactors was developed on the basis of transient cold-shock treatment. The temperature downshift to $10{ }^{\circ} \mathrm{C}$ caused 1.4-fold increase of specific SOD activity compared to unstressed culture. Maximum enzyme productivity was $64 \times 10^{3} \mathrm{U} \mathrm{kg}^{-1} \mathrm{~h}^{-1}$. Two SOD isoenzymes (Cu/ZnSODI and $\mathrm{Cu} / \mathrm{Zn}$-SODII) were purified to electrophoretic homogeneity. The specific activity of the major isoenzyme, Cu/Zn-SODII, after Q-Sepharose chromatography was $4000 \mathrm{U}$ mg

${ }^{-1}$. The molecular mass of SODI (38 $\left.159 \mathrm{Da}\right)$ and of SODII (15 $\left.835 \mathrm{Da}\right)$ was determined by electrospray quadropole time-of-flight (ESI-Q-TOF) mass spectrometry and dynamic light scattering (DLS). The presence of $\mathrm{Cu}$ and $\mathrm{Zn}$ were confirmed by inductively coupled plasma mass spectrometry (ICP-MS). The $\mathrm{N}$-terminal amino acid sequence of $\mathrm{Cu} / \mathrm{Zn}$-SODII revealed a high degree of structural homology with $\mathrm{Cu} / \mathrm{Zn}$-SOD from other fungi, including Aspergillus species.
\end{abstract}

(c) 2016 The British Mycological Society. Published by Elsevier Ltd. All rights reserved.

\section{Introduction}

Superoxide dismutases (SODs, EC 1.15.1.1) are antioxidant enzymes found in all aerobic cells as a first line of defense against superoxide anion radicals $\left(\cdot \mathrm{O}_{2}^{-}\right)$(Fridovich 1998). At high levels, $\cdot \mathrm{O}_{2}{ }^{-}$can affect physiological functions through changes in DNA, proteins, and, lipids, which lead to certain human pathologies including cancers, neurodegenerative

\footnotetext{
* Corresponding author.

E-mail addresses: mariange@microbio.bas.bg, mariange_bg@yahoo.com (M. Angelova). http://dx.doi.org/10.1016/j.funbio.2016.03.002

1878-6146/@ 2016 The British Mycological Society. Published by Elsevier Ltd. All rights reserved.
} 
disorders, and, cardiovascular disease, as well as ageing (see Rowe et al. 2008).

There are four types of SODs grouped according to their catalytic metal cofactor: $\mathrm{Cu} / \mathrm{Zn}-\mathrm{SOD}, \mathrm{Mn}-\mathrm{SOD}, \mathrm{Fe}-\mathrm{SOD}$, and Ni-SOD (Youn et al. 1996; Fridovich 1998).

As is typical for eukaryotes, the filamentous fungi possess two different, evolutionary unrelated forms of SOD, Mn- and $\mathrm{Cu} / \mathrm{Zn}$-containing enzyme. Both isoenzymes have been determined in different fungal species, belonging to the genera Aspergillus, Penicillium, Cladosporium, Mucor, Fusarium, and Alternaria (Angelova et al. 2005), Neurospora crassa (Chary et al. 1994), Humicola lutea (Krumova et al. 2008), various pathogenic fungi (see Fernandes et al. 2008). Only Cu/Zn-SOD has been found in cells of Aspergillus niger 26 (Abrashev et al. 2008; Dolashki et al. 2008). Mn-SOD has been isolated as a single isoenzyme from the thermophilic fungus Chaetomium thermophilum (Guo et al. 2008), the entomopathogenic fungus Beauveria bassiana (Xie et al. 2012), Candida albicans (Lamarre et al. 2001), and several other fungi (Frealle et al. 2006).

The potential therapeutic applications of SOD are based on its scavenging action on the toxic $\cdot \mathrm{O}_{2}{ }^{-}$that may occur in different pathological states. This enzyme might interrupt inflammatory cascades in the cells and thereby limit further disease progression. As has been reviewed by El Shafey et al. (2010), SOD is very useful for the treatment of systemic inflammatory diseases, skin ulcer lesions, degenerative diseases, radiation-induced side effects such as radiation-induced sclerosis and radiation-induced fibrosis (following irradiation for treatment of breast cancer), for stimulation of hair growth, and to reduce hair loss etc. Purified enzyme is used in many pharmaceutical compositions for treatment of diseases including myocardial ischaemia, Peyronie's Disease, multiple sclerosis, colitis, diabetic retinopathy, etc (El Shafey et al. 2010; Raimondi et al. 2010).

The use of exogenous antioxidant, for example SOD, in the assisted reproductive technology (ART) procedures prevents the deleterious effects of oxidative stress on sperm viability and protects functional parameters of spermatozoa (Alvarez 2012; Atig et al. 2012; Agarwal et al. 2014).

In contrast to the industrial use of SOD, the enzyme used therapeutically has to maintain its catalytic activity at lower temperatures. Cold-active (CA) enzymes are known to retain high conformational flexibility at low temperature (Feller \& Gerday 2003; Feller 2013). In recent years these enzymes raised great interest in the area of science and biotechnology. Coldadapted microorganisms are known as good producers of cold-tolerant enzymes (Brenchley 1996; Joseph et al. 2008; Margesin et al. 2008; Nam \& Ahn 2011; Feller 2013). Filamentous fungi isolated from extreme cold environments synthesize CA amylase, xylanase, cellulase, phosphatase, pectinase, lipase, etc (Hou et al. 2006; Kim et al. 2010; Krishnan et al. 2011; Singh et al. 2012). High production of cold-tolerant chitinase by Antarctic fungus Lecanicillium muscarium CCFEE 5003 has been reported (Fenice et al. 2012; Barghini et al. 2013). These fungi could be suitable sources of antioxidant enzymes, especially SOD, because of enhanced level of free radicals caused by harsh conditions (very low temperatures, wide thermal fluctuations, frequent freeze/ thaw cycles, extreme dryness, high salt concentrations, low nutrient availability, high radiation) (Russell 2003, 2006; Onofri et al. 2007; Chattopadhyay et al. 2011).

At the same time, CA SOD is very poorly investigated. Zheng et al. (2006) isolated and characterized CA Fe-SOD from the psychrophilic bacteria Marinomonas sp. NJ522. Later, Pedersen et al. (2009) and Merlino et al. (2010) reported the structure and flexibility of CA Fe-SOD produced by the coldadapted bacteria Aliivibrio salmonicida and Pseudoalteromonas haloplanktis, respectively. But there are no published data about CA SOD from fungi. No information is available also on biotechnological production of such SOD and its application for human in vitro fertilization.

Our previous results showed that the filamentous fungi isolated from the permanent Bulgarian Antarctic base 'St. Kliment Ohridski' on Livingston Island synthesize CA SOD (Tosi et al. 2010). The best producer among thirty tested strains was Aspergillus glaucus 363. The present research was designed to study in more details the conditions for the production of a novel CA SOD by this Antarctic fungus. To develop an effective laboratory technology we used a new approach based on the relationship between oxidative stress and cold shock. Furthermore, the study's aim was to purify the novel enzyme and to characterize it structurally.

\section{Materials and methods}

\section{Fungal strains, culture media, and cultivation}

The fungal strain, Aspergillus glaucus 363 (having optimal growth temperature at $25^{\circ} \mathrm{C}$ ), isolated from Livingston Island (South Shetlands archipelago, Antarctica) (Tosi et al. 2010) was used for the experiments. The strain has been deposited in the National Bank for Industrial Microorganisms and Cell Cultures, Bulgaria (NBIMCC 8861). It is maintained at $4{ }^{\circ} \mathrm{C}$ on beer agar, $\mathrm{pH}$ 6.3. The composition of the seed and production media was as described previously (Angelova et al. 1996). Cultivation was performed in a $3 \mathrm{~L}$ bioreactor ABR-09 developed and constructed by the former Central Laboratory for Bioinstrumentation and Automatisation (CLBA) of the Bulgarian Academy of Sciences. The bioreactor was equipped with temperature, $\mathrm{pH}$, and dissolved oxygen (DO) automatic monitoring and control equipment.

For the submerged cultivation, $74 \mathrm{~mL}$ of seed medium were inoculated with $6 \mathrm{~mL}$ spore suspension at a concentration of $2 \times 10^{8}$ spores $\mathrm{mL}^{-1}$ in $500 \mathrm{~mL}$ Erlenmeyer flasks. The cultivation was performed at $25{ }^{\circ} \mathrm{C}$ for $24 \mathrm{~h}$ on a rotary shaker (220 rpm). For bioreactor cultures, $200 \mathrm{~mL}$ of the seed culture was brought into the $3 \mathrm{~L}$ bioreactor, containing $1800 \mathrm{~mL}$ of the production medium. The cultures were grown at $25^{\circ} \mathrm{C}$ with a stirrer speed of $400 \mathrm{rpm}$ and air flow of 0.5 v.v.m. In the time of the middle exponential phase (18 h), the temperature was reduced to 4 or $10^{\circ} \mathrm{C}$. This downshift was reached in approx. $40 \mathrm{~min}$. After an incubation of $6 \mathrm{~h}$ under cold stress conditions, the temperature was upshifted to the optimal value and the cultivation continued until the 72 nd hour. The 
control variants were grown at optimal temperature during the whole period.

\section{Cell-free extract preparation and enzyme activity determination}

The cell-free extracts were prepared as previously described in detail (Krumova et al. 2008). All steps were performed at $0-4{ }^{\circ} \mathrm{C}$. SOD activity was measured by the nitro-blue tetrazolium (NBT) reduction method of Beauchamp \& Fridovich (1971). One unit of SOD activity was defined as the amount of enzyme required for inhibition of the reduction of NBT by $50 \%\left(A_{560}\right)$ and was expressed as units per mg protein (U mg ${ }^{-1}$ protein).

\section{SOD purification}

Cell free extract from 36-h culture from Aspergillus glaucus was clarified by filtration through celite and Millipore's device Pellicon XL Durapore 0.1, concentrated and fractionated by ultrafiltration with Pellicon XL $10(10 \mathrm{kDa})$. All purification steps were carried out at $4{ }^{\circ} \mathrm{C}$ using an FPLC system (ÄKTA purifier GE Healthcare Life Sciences, USA).

Step 1. Superdex 100 column chromatography (gel filtration). Active fractions were concentrated and applied to a column Superdex (10/300 GL), pre-equilibrated with $20 \mathrm{mM}$ Tris-HCl buffer with $\mathrm{pH} 7.8$ including $100 \mathrm{mM}$ $\mathrm{NaCl}$. The protein was eluted with the same buffer at a flow rate of $0.25 \mathrm{~mL} \mathrm{~min} \mathrm{~m}^{-1}$ at $4{ }^{\circ} \mathrm{C}$.

Step 2. Phenyl-Sepharose column chromatography (hydrophobic interaction chromatography). For additional removal of accompanying proteins, the active fraction from Superdex column was brought to $40 \%$ ammonium sulphate saturation (0.02 $\mathrm{M}$ potassium phosphate buffer at $\mathrm{pH}$ 7.8). The dialysed enzyme solution was loaded onto a Phenyl-Sepharose column equilibrated with the above buffer at a flow rate of $120 \mathrm{~mL} \mathrm{~h}^{-1}$. The residual protein was eluted with $15 \%$ buffered solution of ammonium sulphate.

Step 3. Q-Sepharose column chromatography (ion-exchange chromatography). The active peak fractions from Phenyl-Sepharose column were pooled, concentrated, and applied to a column of Q-Sepharose pre-equilibrated with $20 \mathrm{mM}$ Tris-HCl buffer with $\mathrm{pH} 7.8$ including $100 \mathrm{mM} \mathrm{NaCl}$. Unbound enzyme protein was eluted with the same buffer; bound enzyme protein (major isoenzyme) was eluted with buffer containing $0.6 \mathrm{M} \mathrm{NaCl}$. The enzyme activity was recovered in both fractions (bound and unbound). At each stage of purification, active fractions were analysed for SOD activity.

\section{DNA isolation procedure}

Fifteen millilitre yeast extract peptone-dextrose (YEPD) medium ( $\mathrm{g} \mathrm{L}^{-1}$ : yeast extract 10.0 , peptone 20.0 , glucose 10 ) were inoculated with a single fungal colony and incubated in $100 \mathrm{~mL}$ Erlenmeyer flasks. After incubation for $48 \mathrm{~h}$ on a rotary shaker at $180-200 \mathrm{rpm}$ and $25^{\circ} \mathrm{C}$ the resulting pellet was collected and washed with $5 \mathrm{~mL} 0.98 \%$ saline solution. The pellet was ground in a mortar with quartz sand. Two millilitre $1 \times$ Tris-EDTA (TE) buffer (10 mM Tris/HCl, pH 8.0, 1 mM EDTA) were added to the cell lysates and the homogenates dispensed in Eppendorf tubes $\left(500 \mu \mathrm{L}\right.$ tube $\left.^{-1}\right)$. The DNA isolation was performed according to Maniatis et al. (1982). The DNA was purified via GFX columns (GE Healthcare, Little Chalfont, Buckinghamshire, England). Its quality and quantity was checked by measurement of the UV absorption, and used as a template for PCR amplification experiments.

\section{PCR conditions and DNA sequencing}

The amplification was performed on an Eppendorf Mastercycler personal thermocycler (Eppendorf AG, Hamburg, Germany) using PuReTaq ${ }^{\text {TM }}$ Ready-To-Go'M PCR beads (Amersham Biosciences, Piscataway, NJ, USA). The final concentration of primers in the reaction mixture was $0.4 \mathrm{pmol} \mu \mathrm{L}^{-1}$. The concentration of the DNA matrix was $50 \mathrm{ng} / 25 \mu \mathrm{L}$ (final volume of the reaction mixture).

The universal primers used for fungal 18S rDNA amplification were PFf (AGGGATGTATTTATTAGATAAA AAATCAA) and PFr (CGCAGTAGTTAGTCTTC AGTAAATC) (Jaeger et al. 2000). PCR conditions: initial step, $95^{\circ} \mathrm{C}, 5 \mathrm{~min}$; amplification - 35 cycles, $95{ }^{\circ} \mathrm{C}, 30 \mathrm{~s} ; 58^{\circ} \mathrm{C}, 30 \mathrm{~s} ; 72{ }^{\circ} \mathrm{C}, 45 \mathrm{~s}$; extension step, $72{ }^{\circ} \mathrm{C}$, $7 \mathrm{~min}$.

The obtained PCR products were purified by the GFX TM PCR DNA and gel band purification kit (GE Healthcare). All DNA amplified fragments were sequenced on an ABI Prism $310 \mathrm{Ge}$ netic Analyser (Applied Biosystems, Foster City, CA, USA). The reaction mixture for DNA sequencing contained $2 \mu \mathrm{L}$ of purified PCR product $\left(2 \mathrm{ng} \mu \mathrm{L}^{-1}\right), 1.3 \mu \mathrm{L}$ Big Dye ${ }^{\circledR}$ terminator kit v. 3.1, $2 \mu \mathrm{L} 5 \times$ sequencing (Seq) buffer, $0.35 \mu \mathrm{L}$ primers $\left(10 \mathrm{pmol} \mu \mathrm{L}^{-1}\right)$. The volume was brought to $10 \mu \mathrm{L}$ with distilled water.

\section{Comparative sequence analysis}

The raw data obtained from the sequencing were checked for errors by the program Sequence Scanner V1.0 (Applied Biosystems). DNA sequences were formatted in a form suitable for comparison by the BLAST analysis database of National Center for Biotechnology Information (NCBI). The corresponding protein sequences were established from the DNA sequence using DNASTAR Inc., Madison, WI software. The pair and multiple sequence alignment were performed using ClustalW2.

\section{Analytical methods}

Soluble reducing sugars were determined by the Somogyi-Nelson method (Somogyi 1952). Protein was estimated by the Lowry procedure (Lowry et al. 1951) using solution of bovine serum albumin as standard. The dry weight determination was performed on samples of mycelia harvested throughout the culture period. The culture fluid was filtered through a Whatman (Clifton, USA) No. 4 filter. The separated mycelia were washed twice with distilled water and dried to a constant weight at $105^{\circ} \mathrm{C}$.

The possible glycosylation of SODI and SODII was checked by a qualitative modification of the colourimetric method of 
Dubois et al. (1956) in phenol-sulphuric acid. Dynamic light scattering (DLS) was performed on a DynaPro NanoStar instrument (Wyatt Technology Corporation) operated in batch mode at $20^{\circ} \mathrm{C}$ and fitted with a laser beam emitting at $658 \mathrm{~nm}$. Samples were filtered on Whatman Anotop 10 inorganic membrane $(0.02 \mu \mathrm{m}$ cut off) and loaded into a $10 \mu \mathrm{L}$ quartz microcuvette. Scattering data were analysed using DYNAMICS v. 7.1.1.3 software (Wyatt Technology Corp.). A globular protein model was used for mass estimation. Mass determination was performed on an electrospray quadropole time-offlight (ESI-Q-TOF) instrument (Waters, Micromass) in positive ion mode. Samples $(10 \mu \mathrm{M})$ were analysed in $30 \%$ acetonitrile, $0.5 \%$ formic acid, $25 \mathrm{mM}$ ammonium acetate. Spectra deconvolution technique of calculation was the maximum entropy (Max ent1). The metal content of the purified proteins was determined by inductively coupled plasma mass spectrometry (ICP-MS) at the Malvoz Institute, Laboratory of Environmental Chemistry (Liège, Belgium) for $\mathrm{Cu}, \mathrm{Zn}, \mathrm{Mn}, \mathrm{Fe}$, and Ni. Differential scanning microcalorimetry was performed using a MicroCal VP-DSC instrument at a scan rate of $60 \mathrm{~K} \mathrm{~h}^{-1}$ and under $\sim 25$ psi positive cell pressure. Samples were dialysed overnight against $30 \mathrm{mM}$ 3-(N-morpholino) propanesulfonic acid (MOPS), $50 \mathrm{mM} \mathrm{NaCl}, \mathrm{pH}$ 7.5. Both the sample and the reference buffer were brought to $0.5 \mathrm{M}$ 3-(1-pyridinio)-1propanesulfonate (i.e. a nondetergent sulfobetaine) in order to prevent aggregation. The $\mathrm{N}$-terminal amino acid sequence was determined by automated Edman degradation using a pulsed-liquid-phase protein sequencer Procise 494 (Applied Biosystems) fitted with an on-line phenylthiohydantoin analyser.

Sodium dodecyl sulphate polyacrylamide gel electrophoresis (SDS-PAGE, $12 \%$ gel) was used to verify the protein purity of the enzyme under denaturing conditions, as was described by Laemmli (1970). Protein marker was from Pharmacia (Sweden) with a broad range of 14-97 kDa. Protein bands were visualized by Coomassie brilliant blue R-250 (Bio-Rad, USA) staining. Zones of SOD activity were stained with NBT using $10 \%$ nondenaturing PAGE, as described by Beauchamp \& Fridovich (1971).

\section{Results}

\section{Taxonomic identification of the fungal strain}

Using classical taxonomy based on morphology, the producer of CA SOD was previously identified as Aspergillus glaucus (Tosi et al. 2010). Molecular methods have been widely applied to the identification of a large number of Aspergillus species. The study of the 18S rDNA sequences can provide important complementary information for the definition of species and their appropriate identification. In the present work, confirmation of the morphological identification by molecular methods was done.

The molecular taxonomic affiliation of the investigated Antarctic fungal strain was performed on the bases of the comparison with 18S rDNA sequences of reference organisms published in the gene sequence database of NCBI Data Bank. The validation of the genotypic us. the phenotypic analyses indicated that the investigated strain is closely related to the species A. glaucus.

\section{Sequence analyses of the SOD gene}

For the nucleotide sequence of the $\mathrm{Cu} / \mathrm{Zn}$-SOD gene, a pair of oligonucleotide primers (AFCUF 5'TTGCTGTCCTCCGCGGTGACTC CA3' and AFCUR 5'ATGACACCACAGGCGGGACGAG3') was designed on the basis of the $\mathrm{Cu} / \mathrm{Zn}-\mathrm{SOD}$ gene of Aspergillus fumigatus Af293 (Nierman et al. 2005). The PCR product (about $650 \mathrm{bp)} \mathrm{obtained}$ from genomic DNA of the strain was electrophoretically analysed and found to have appropriate profile. It was purified and sequenced. The obtained partial DNA gene sequence consisted of $484 \mathrm{bp}$ and is provided in Fig 1.

The BLAST analysis demonstrated similarity of the sequenced fragment with genes coding for enzymes with $\mathrm{Cu}$ / Zn-SOD activity. It comprised two putative introns consisting of 53 and 65 bases corresponding to the second and third introns identified in A. fumigatus (Lima et al. 2007). The coding region (Fig 1) was aligned with the sequences in the NCBI GenBank. There was $100 \%$ identity of the nucleotide sequence of the $\mathrm{Cu} / \mathrm{Zn}$-SOD gene obtained with the corresponding $\mathrm{A}$. fumigatus Af293 sequence NCBI Acc. No. XM_748622.1 and A. fumigatus AF128886.1. Furthermore, the sequence identity of the investigated gene with the $\mathrm{Cu} / \mathrm{Zn}$-SOD gene of Neosartoria fishery (NCBI Acc. No. XM_001259765.1) was $98 \%$ and the identity with the closest similar gene in Penicillium (Penicillium chrysogenum Wisconsin 54-1255 NCBI Acc. No. XM_002568648.1) was $84 \%$.

The deduced protein sequence consisted of 121 amino acids (Fig 2). The protein sequence comparison by the BLASTP 2.2.26+ program revealed $100 \%$ identity with $\mathrm{Cu} / \mathrm{Zn}$ SOD (SOD1) of the referent strain A. fumigatus Af293. The similarities established with other members of the $\mathrm{Cu} / \mathrm{Zn}$-SOD enzyme's superfamily varied between $100 \%$ and $71 \%$.

\author{
TTGCTGTCCTCCGTGGTGACTCCAAGATCACCGGCACTGTCACCTTCGAGCAGGC \\ CGACGAGAACTCTCCCACCACCGTCTCTTGGAACATCAAGGGCAACGACCCCAAC \\ GCCAAGCGTGGCTTCCATGTCCACCAGTTCGGTGACAACACCAACGGCTGCACCT \\ CCGCTGGTCCTCACTgtatgtcctcttcccagtggtcactctgagaaccagaactgaccgacctccagTCAACCCC \\ TATGGCAAGACCCATGGAGCTCCTGAGGACTCCGAGCGCCATGTCGGTGACCTTG \\ GTAACTTCGAGACCGATGCTGAGGGTAACGCCGTCGGCTCCAAGCAGGACAAGC \\ TTATTAAGCTGATTGGTGCCGAGAGCGTTCTGGGCgtaagttttttttttctgcagatggtaatgcataga \\ gttaacagtgagctgacaacaatgttagCGGACCTTGGTCGTTCACGCCGGTACCGACGACC
}

Fig 1 - Partial nucleotide sequence of Cu/Zn-SOD gene from the Aspergillus glaucus 363 (GenBank: JN206685.1). The two introns are indicated by lowercase letters. 


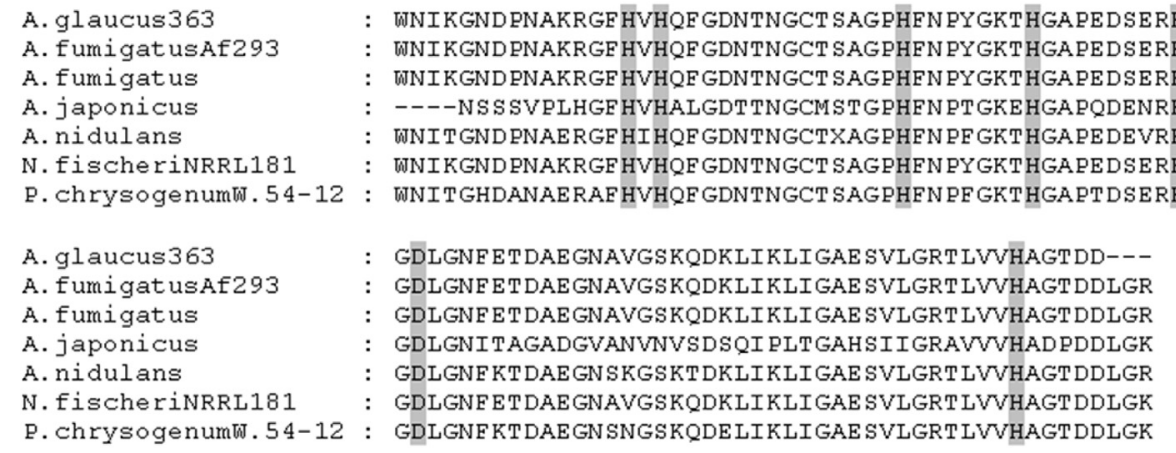

Fig 2 - Multiple alignment of the amino acid sequences of the metal binding region of $\mathrm{Cu} / \mathrm{Zn}$-SOD enzymes from different fungi.

The multiple sequence alignment analysis showed the existence of key amino acids' residues responsible for $\mathrm{Cu}^{2+}$ (His43, His45, His59, His116) and $\mathrm{Zn}^{2+}$ (His59, His67, His76, Asp79) binding in positions cited by other researchers (Lin et al. 2008). The comparison of the deduced amino acid sequence of Aspergillus glaucus strain $363 \mathrm{Cu} / \mathrm{Zn}-\mathrm{SOD}$ protein fragment with the similar proteins in different fungi demonstrated very conservative structure of the active site regions (Fig 2).

\section{Production of CA SOD}

During the course of previous investigation on Antarctic fungi, a high level of CA SOD in Aspergillus glaucus 363 was detected (Tosi et al. 2010). Furthermore, short-term treatment of exponentially growing culture of A. glaucus 363 with low temperatures enhanced the level of oxidative stress that resulted in the activation of antioxidant enzyme defence (Kostadinova et al. 2012). Based on the above mentioned findings, a transient cold-stress was applied in order to increase the yield of the first antioxidant enzyme SOD. Changes in biomass content, glucose consumptions, intracellular protein synthesis, and SOD production after $6 \mathrm{~h}$ temperature downshift and subsequent recovery at the optimum temperature were evaluated (Fig 3). In the control experiment (Fig 3A), the growth (maximum d.w. $2.16 \mathrm{~g} / 100 \mathrm{~mL}$ ) and protein synthesis rose simultaneously until the $48 \mathrm{~h}$ of cultivation coinciding with a rapid glucose uptake. Maximum SOD activity (about $29 \mathrm{U} \mathrm{mg}^{-1}$ protein) was recorded $36 \mathrm{~h}$ after inoculation. The transient exposure to 10 or $4{ }^{\circ} \mathrm{C}$ (Fig 3B and C, respectively) caused a delay in biomass formation and prolongation of the exponential growth phase, a decrease in the protein level and activation of antioxidant defence. Maximum mycelia growth of 1.9 and $1.8 \mathrm{~g} / 100 \mathrm{~mL}$, respectively, was achieved after $72 \mathrm{~h}$ of incubation. Thus, the biomass content was between $11 \%$ and $17 \%$ lower than in the control variant. The same trend of decreasing was observed for the intracellular protein content. In contrast, short-term treatment with cold temperatures resulted in significant increase in SOD activity compared to the control and this increase remained even after recovery of the optimal temperature. The cultures exposed to $10{ }^{\circ} \mathrm{C}$ demonstrated $34 \%$ higher specific SOD activity, while the antioxidant response of the cold-treated cells at $4{ }^{\circ} \mathrm{C}$ resulted in $71 \%$ increase in SOD level. It should be noted that the maximum enzyme activity in the cultures exposed to $4{ }^{\circ} \mathrm{C}$ was realized after the 48th hour.

\section{Comparison of the efficiency of SOD biosynthesis by Aspergillus glaucus 363 grown under different conditions}

Comparison of kinetic relations (substrate consumption and product formation parameters) for CA SOD production between three variants of bioreactor cultures (control, cold stress at $10{ }^{\circ} \mathrm{C}$, and cold stress at $4{ }^{\circ} \mathrm{C}$ ) is given in Table 1 . The results indicated that the highest value of the kinetic parameters for biomass and yield of protein were observed in the control cultures. But, the application of $6 \mathrm{~h}$ cold stress resulted in enhanced both specific and total SOD production. Moreover, enzyme yield coefficient $\left(\mathrm{U} \mathrm{g}^{-1}\right)$ and SOD productivity $\left(\mathrm{U} \mathrm{kg}^{-1} \mathrm{~h}^{-1}\right)$ were significantly higher than in the unstressed cells. Despite the reduced yield of biomass $\left(\mathrm{g} \mathrm{L}^{-1}\right)$ and protein $\left(\mathrm{mg} \mathrm{L}^{-1}\right)$ after temperature downshift, the increased specific SOD activity led to the enhanced value of total SOD activity and enzyme yield coefficient (Yp/x). The Yp/x demonstrated $25 \%$ and $28 \%$ increase at 10 and $4{ }^{\circ} \mathrm{C}$, respectively, compared to the control. It should be noted however that this increase at $4{ }^{\circ} \mathrm{C}$ was detected later (after $48 \mathrm{~h}$ vs. $36 \mathrm{~h}$ at $10^{\circ} \mathrm{C}$ ). Thus, the most effective SOD production was observed after cold stress at $10^{\circ} \mathrm{C}$. As seen in Table 1 , the SOD productivity is highest after exposure at $10^{\circ} \mathrm{C}$, compared to the control and to the cold stress at $4^{\circ} \mathrm{C}$.

\section{Purification of Aspergillus glaucus SODs}

In a previous paper we reported the presence of three SOD isoenzymes in the cell-free extract from A. glaucus 363 (Kostadinova et al. 2012). They were designated as Mn-SOD, $\mathrm{Cu} / \mathrm{Zn}$-SODI, and $\mathrm{Cu} / \mathrm{Zn}$-SODII in the order of their migration towards the anode. The most abundant isoforms are $\mathrm{Cu} / \mathrm{Zn}$ SODI and $\mathrm{Cu} / \mathrm{Zn}$-SODII. In the present study, the cell-free extract $(1500 \mathrm{~mL}$ ) obtained from $150 \mathrm{~g}$ fresh biomass (29 $\mathrm{g} \mathrm{d.w.)}$ was used in the experiments. The purification protocol included concentration by ultrafiltration, gel filtration on Superdex 100, hydrophobic interaction chromatography on PhenylSepharose, followed by a final ion-exchange chromatography on Q-Sepharose to produce a homogenous enzyme. Summary 

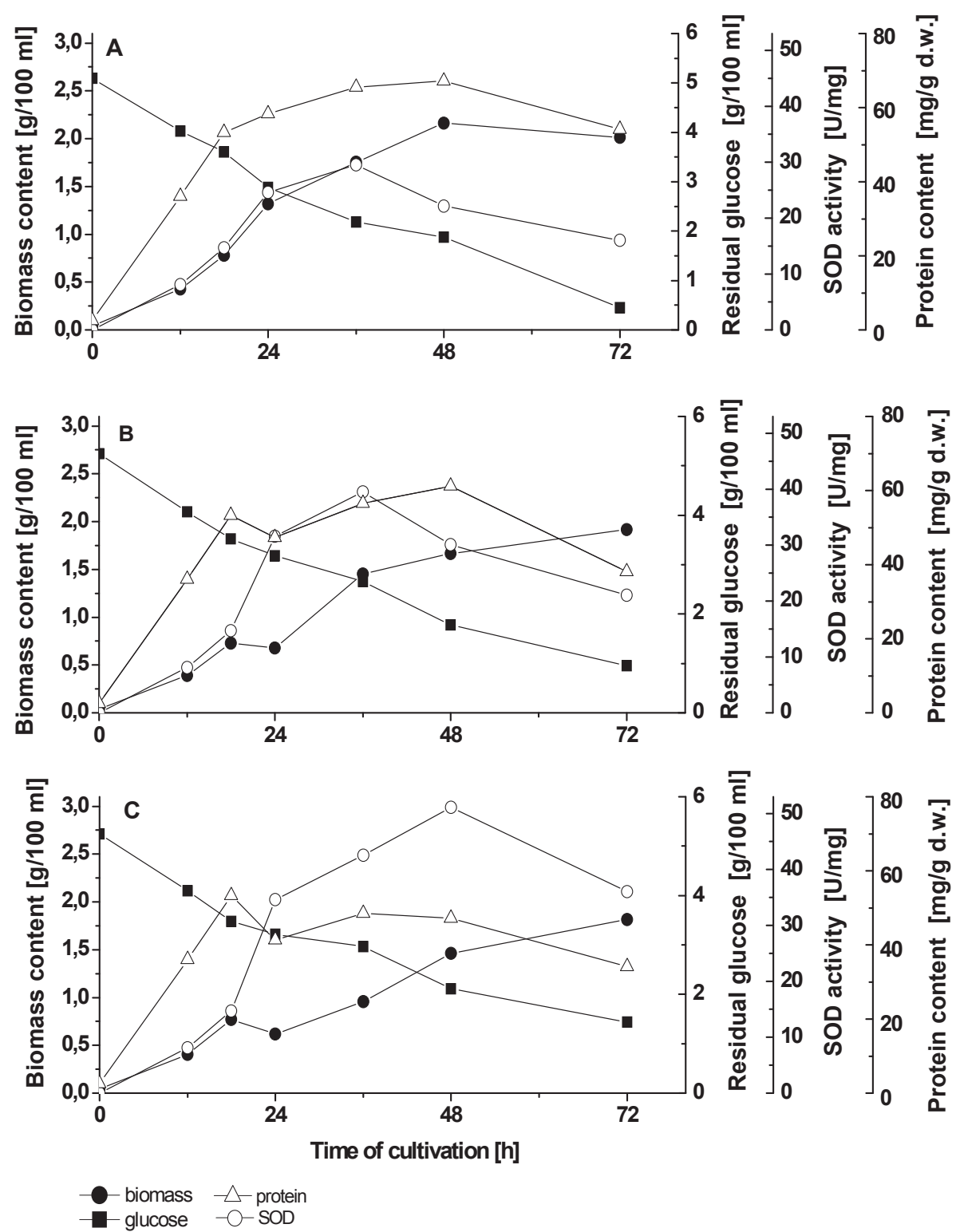

Fig 3 - Time courses of mycelia growth $(\Delta)$, SOD production $(O)$, residual glucose $(\square)$, and intracellular protein content $(\Theta)$ in the fungal cultures during fermentation in $3 \mathrm{~L}$ bioreactor. A - growth at optimal temperature; B - growth after $6 \mathrm{~h}$ cold stress at $10{ }^{\circ} \mathrm{C}$ and the subsequent restoration of the normal conditions; $\mathrm{C}$ - growth after $6 \mathrm{~h}$ cold stress at $4{ }^{\circ} \mathrm{C}$ and the subsequent restoration of the normal conditions.

of purification procedures is presented in Table 2 and Fig $4 \mathrm{~A}, \mathrm{~B}$, C. In the first step, Superdex fast flow gel filtration successfully separated ultrafiltered solution into fractions by their molecular mass (Fig 4A). This chromatography enables the achievement of an 11-fold increase in the specific activity and enzyme yield of $35 \%$. Further purification was achieved by hydrophobic interaction chromatography on Phenyl-Sepharose column, giving rise to one active peak (Fig 4B) with specific activity of $749 \mathrm{U} \mathrm{mg}^{-1}$ protein, which was 28.8 -fold higher than that of the crude enzyme with $8.1 \%$ yield. PAGE analysis after Superdex and Phenyl-Sepharose column showed that the active peak contained also the above mentioned SOD bands (Cu/Zn-SODI and $\mathrm{Cu} / \mathrm{Zn}-\mathrm{SODII}$ ), except for Mn-SOD (Fig 5A, lane $1 ; B$, lane 1). These two enzymes were separated by chromatography on Q-Sepharose (Fig 4C). The major isoenzyme, $\mathrm{Cu} / \mathrm{Zn}$-SODII, was purified to homogeneity with a specific activity of $4000 \mathrm{U} \mathrm{mg}^{-1}$, 153-fold purification, and an overall activity yield of $9.7 \%$ (Fig 5A, lane 2; B, lane 2). The minor isoenzyme, $\mathrm{Cu} / \mathrm{Zn}-\mathrm{SODI}$, gave a specific activity of $610 \mathrm{U} \mathrm{mg}^{-1}$ with 23 -fold purification and $0.65 \%$ yield (Fig 5A, lane 3; B, lane 3).

\section{Characterization of Aspergillus glaucus SODs}

Table 3 summarizes the results of SODI and SODII characterization. The possible protein glycosylation was checked by a qualitative colourimetric method in phenol-sulphuric acid. SODI responded positively to this test whereas SODII 
Table 1 - Comparison of SOD productivities in unstressed and cold-stressed cultures ${ }^{\mathbf{a}}$.

\begin{tabular}{|c|c|c|c|c|c|c|c|}
\hline $\begin{array}{l}\text { Cultivation } \\
\text { system }^{\mathrm{a}}\end{array}$ & $\begin{array}{c}\text { Cultivation } \\
\text { time [h] }\end{array}$ & $\begin{array}{l}\mathrm{DW}^{\mathrm{b}} \\
{\left[\mathrm{g} \mathrm{L}^{-1}\right]}\end{array}$ & $\begin{array}{l}\text { Yield of protein }{ }^{c} \\
{\left[\mathrm{mg} \mathrm{L}^{-1}\right]}\end{array}$ & $\begin{array}{c}\text { Specific SOD } \\
\text { activity }^{\mathrm{d}} \\
{\left.\text { [U (mg protein })^{-1}\right]}^{\text {(mg prote }}\end{array}$ & $\begin{array}{c}\text { Total SOD } \\
\text { activity }^{\mathrm{e}} \\
{\left[\mathrm{U} \mathrm{L}^{-1}\right] \times 10^{3}}\end{array}$ & $\begin{array}{c}\text { Yield coefficient }{ }^{\mathrm{f}} \\
(\mathrm{Yp} / \mathrm{x})\left[\mathrm{U} \mathrm{g}^{-1}\right] \times 10^{3}\end{array}$ & $\begin{array}{l}\text { SOD productivity } \\
{\left[\mathrm{U} \mathrm{kg}^{-1}\right] \mathrm{h}^{-1} \times 10^{3}}\end{array}$ \\
\hline $\begin{array}{l}\text { Unstressed } \\
\text { culture }\end{array}$ & 36 & 17.52 & 1095.00 & 29.5 & 32.3 & 1843.7 & 51.3 \\
\hline \multicolumn{8}{|l|}{$\begin{array}{l}\text { Stressed } \\
\text { culture }\end{array}$} \\
\hline $10^{\circ} \mathrm{C}$ & 36 & 14.52 & 845.38 & 39.5 & 33.4 & 2299.7 & 63.89 \\
\hline $4{ }^{\circ} \mathrm{C}$ & 48 & 14.74 & 680.72 & 51.1 & 34.7 & 2363.1 & 49.2 \\
\hline
\end{tabular}

a A. glaucus was cultivated as unstressed and stressed ( $4 \mathrm{~h}$ at 10 or $4{ }^{\circ} \mathrm{C}$; see Materials and methods) cultures.

b Biomass content as dry weight at the time of harvest.

c Yield of protein is calculated as mg intracellular protein in the dry biomass, produced per litre of culture medium.

d Activities at the time of harvest.

e Total SOD activity is calculated as amount of enzyme per dry weight biomass, produced per litre of culture medium.

f SOD yield coefficient is calculated as amount of enzyme per kg dry biomass.

$\mathrm{g}$ SOD productivity is calculated as amount of enzyme per kg dry biomass produced per hour.

was found to be free of glycosylation. The size distribution of both SODs in solution was analysed by DLS. The hydrodynamic radius of SODI $(2.9 \mathrm{~nm})$ can accommodate a modelled globular protein of about $40 \mathrm{kDa}$ and the radius of SODII $(1.8 \mathrm{~nm})$ corresponds to a globular protein of about $14 \mathrm{kDa}$. Furthermore, the low polydispersity parameter (distribution of sizes) below $10 \%$ for both SODs indicates monodisperse and very homogenous monomer populations, without evidence for dimers or higher oligomers. The mass of both SODs was determined more precisely by ESI-Q-TOF mass spectrometry. The mass of SODI (38 $159 \mathrm{Da}$ ) and of SODII (15 $835 \mathrm{Da}$ ) confirmed the estimates provided by DLS.

The metal content of both SODs was further determined by ICP-MS. In the case of SODII, ICP-MS indicates a 1/1 molar ratio (metal/protein) for $\mathrm{Cu}$ and $\mathrm{Zn}$, without significant amounts of $\mathrm{Fe}, \mathrm{Mn}$ or Ni. Accordingly, this low molecular weight (MW) SOD clearly belongs to the $\mathrm{Cu} / \mathrm{Zn}$-SOD type. For SODI, the following molar ratios (metal/protein) were found: $\mathrm{Cu}=0.7$; $\mathrm{Zn}=0.4 ; \mathrm{Mn}=0.16$. These ratios suggest that the high $\mathrm{MW}$ SOD is also a $\mathrm{Cu} / \mathrm{Zn}$-SOD. These low ratios also suggest that its metal binding affinity is weak, resulting in the loss of metal ions during the purification process as both metals were lacking in the buffers. Finally, the melting temperature $T_{m}$ was recorded by differential scanning calorimetry. SODII displays a $T_{m}$ value of $80^{\circ} \mathrm{C}$ and therefore its structure is rather stable

\section{Table 2 - Purification of $\mathrm{Cu} / \mathrm{Zn}$-SOD from A. glaucus cells.}

\begin{tabular}{|c|c|c|c|c|}
\hline Step & $\begin{array}{l}\text { Total SOD } \\
\text { activity } \\
\text { (units) }\end{array}$ & $\begin{array}{c}\text { Specific SOD } \\
\text { activity } \\
\left(\mathrm{U} \mathrm{mg}{ }^{-1}\right)\end{array}$ & $\begin{array}{l}\text { Yield } \\
(\%)\end{array}$ & $\begin{array}{l}\text { Purification } \\
\text { (fold) }\end{array}$ \\
\hline Cell-free extract & 66838 & 26 & 100 & 1.0 \\
\hline Superdex & 7887 & 142 & 35 & 11.8 \\
\hline Phenyl-Sepharose & 5416 & 749 & 8.1 & 28.8 \\
\hline $\begin{array}{l}\text { Q-Sepharose I } \\
\text { peak }\end{array}$ & 6500 & 4000 & 9.7 & 153.4 \\
\hline $\begin{array}{l}\text { Q-Sepharose II } \\
\text { peak }\end{array}$ & 430 & 610 & 0.65 & 23.5 \\
\hline
\end{tabular}

to temperature. By contrast, SODI is more heat-labile $\left(\mathrm{T}_{\mathrm{m}}=54^{\circ} \mathrm{C}\right)$. This can explain the low metal content of SODII as heat-labile psychrophilic proteins generally bind their cofactors with low affinity (Feller 2013).

The N-terminal amino acid sequence of SODII determined by automated Edman degradation corresponded to VKAVAVLRGDSKITG. A BLAST search (http://web.expasy.org/ blast/) of this sequence against the whole databases retrieved only $\mathrm{Cu} / \mathrm{Zn}$ SODs from fungi, including Aspergillus species. All these SODs are small proteins (153-155 amino acids, including the initial formyl-methionine), with masses in the range 15 800-15 $900 \mathrm{Da}$ and binding one $\mathrm{Cu}$ ion and one $\mathrm{Zn}$ ion. More specifically, this sequence is $100 \%$ identical to N-terminal sequences of the fungi Humicola lutea, Aspergillus fumigatus, Thermoascus aurantiacus, and Aspergillus fischerianus. Attempts to determine the $\mathrm{N}$-terminal sequence of SODI were unsuccessful.

\section{Discussion}

Antarctica constitutes a large unrevealed reservoir of coldadapted organisms, including fungi that can be exploited as producers of valuable thermo-sensitive enzymes. Our previous studies evidenced that Antarctic fungi possess powerful enzymatic systems and synthesized CA antioxidant enzymes, SOD, and catalase (Tosi et al. 2010). The present paper reports that Aspergillus glaucus 363 is an effective producer of $\mathrm{Cu} / \mathrm{Zn}$ SOD. The strain contains at least one gene encoding $\mathrm{Cu} / \mathrm{Zn}$ SOD that exhibited high homology with the corresponding gene of Aspergillus fumigatus Af293 and A. fumigatus AF128886. To our knowledge, this is the first nucleotide sequence of a $\mathrm{CA} \mathrm{Cu} / \mathrm{Zn}-\mathrm{SOD}$ gene in fungi. Identification of genes encoding CA SOD synthesis is very seldom published. Until now, such identification has been carried out in bacterial strains Aliivibrio salmonicida (Fe-SOD, sodB) and Psychromonas arctica (Pedersen et al. 2009; Na et al. 2011).

Although A. glaucus 363 was isolated from samples taken from Antarctica, this strain belongs to the mesophilic temperature group (Tosi et al. 2010). Mesophilic fungi have been found in different cold ecosystems (Margesin et al. 2008). According 

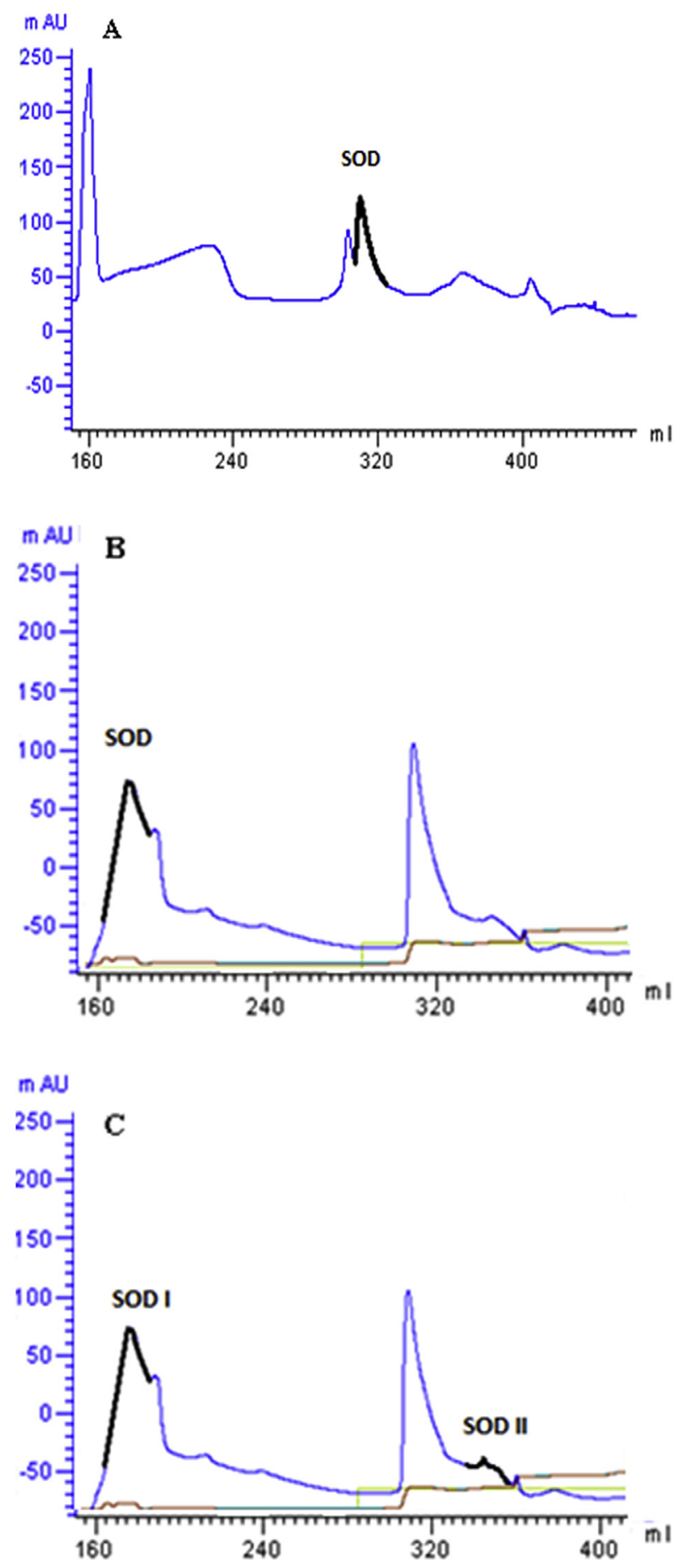

Fig 4 - Chromatographic patterns observed during purification of A. glaucus SOD. SOD samples were applied to a column of Sephadex (A), Phenyl-Sepharose (B), and Q-Sepharose (C).

to Zucconi et al. (1996), such fungi can be assigned to dominant indigenous or mesophilic psychrotolerant species. Moreover, the produced SOD by A. glaucus 363 retains psychrophilic characteristics. The majority of CA enzymes of microbial
A

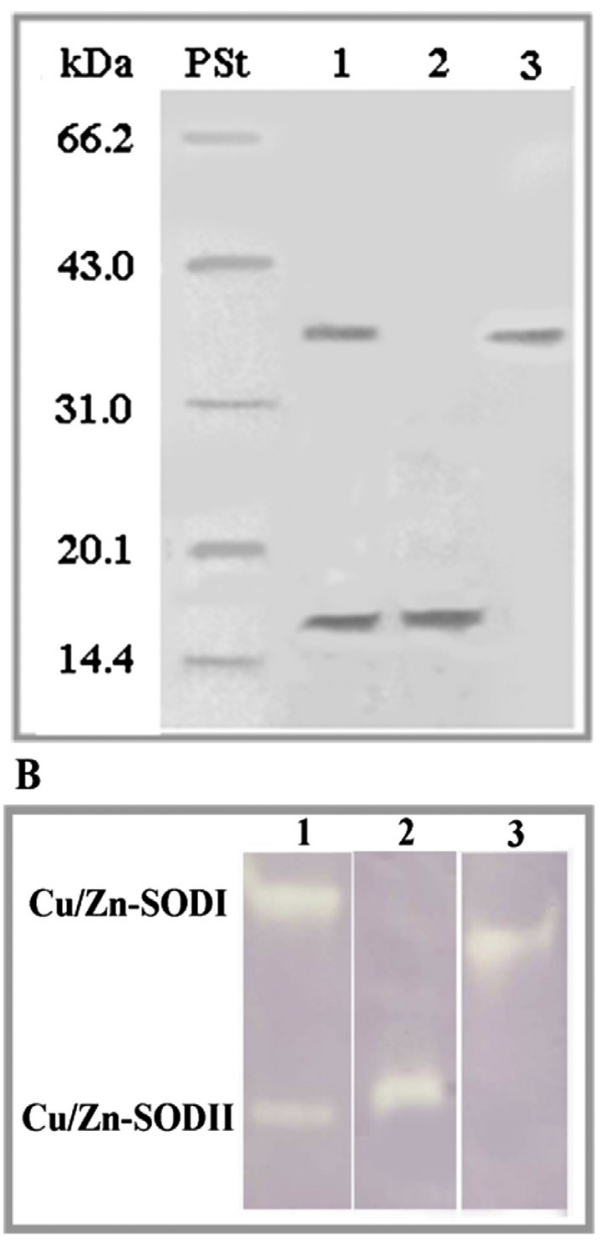

Fig 5 - PAGE analyses of A. glaucus SOD isoenzymes after different step of purification. (A) SDS-PAGE and protein staining; (B) native PAGE staining for activity. PSt - protein standards; 1 - after Phenyl-Sepharose column; 2 and 3 after Q-Sepharose chromatography.

origin are produced by psychrophilic or psychrotolerant strains. However, some mesophilic microorganisms can also synthesize thermo-sensitive enzymes. A similar phenomenon has been reported for CA lipase found in mesophilic bacteria, yeasts, and fungi (see Yuan et al. 2010; Bae et al. 2014). The mesophilic fungal strain Trichoderma reesei produces several thermo-sensitive hydrolases (Nevaleinen et al. 2012).

Generally, more reactive oxygen species (ROS) are produced in stressed cells, which cause cellular damages. The overexpression of SODs can lead to protection against specific stresses, implying that SOD may be the first line of defense against ROS (Fridovich 1998). The present results suggest that manipulation of the cell redox state allows the development of fungal cultures with improved antioxidant defence (Fig 3). Besides the transient character of the cold stress, the enhancement of SOD activity was observed until the end of cultivation. Our previous studies have demonstrated that the increased level of ROS generated during the temperature 
Table 3 - Characterization of A. glaucus SODs.

\begin{tabular}{lll} 
& \multicolumn{1}{c}{ SODI } & \multicolumn{1}{c}{ SODII } \\
\hline Glycosylation & + & - \\
Hydrodynamic radius & $2.9 \mathrm{~nm}$ & $1.8 \mathrm{~nm}$ \\
Polydispersity & $10 \%$ & $6 \%$ \\
Mass by ESI-Q-TOF & $38159 \pm 4 \mathrm{Da}$ & $15835 \pm 2 \mathrm{Da}$ \\
Metal content (molar ratio) & & \\
$\mathrm{Cu}$ & 0.7 & 1 \\
Zn & 0.4 & 1 \\
Melting point & $54^{\circ} \mathrm{C}$ & $80^{\circ} \mathrm{C}$ \\
\hline
\end{tabular}

downshift induced SOD biosynthesis in A. glaucus 363 (Kostadinova et al. 2012). Similar approach has been used for improving SOD activity in different pro- and eukaryotic organisms (Smirnova et al. 2001; Baek \& Skinner 2012; Kayihan et al. 2012; Xu et al. 2013). High ROS concentrations generated by exposure to $\mathrm{H}_{2} \mathrm{O}_{2}$, high DO, and superoxide-generating chemicals were reported to cause activation of SOD synthesis (Angelova et al. 2005; Li et al. 2009). According to Baez \& Shiloach (2013), superoxide stress regulator (SoxRS) and SOD are the main defence mechanism that protects bacteria from the toxic effects of high oxygen saturation.

Due to the wide range of SOD applications, numerous direct and indirect methods have been developed for production of mesophilic enzyme. Both native and recombinant SODs are now available (Xie et al. 2010; Zhu et al. 2013; Tuteja et al. 2015). Despite great efforts, efficient production of recombinant SOD in heterologous host has failed because of deficit in its metal cofactors (Bafana et al. 2011). Thus, more efficient microbial technologies need to be elaborated. Indeed, there is no information also about technology for CA SOD production. We used the relationship between low temperature treatment and enhanced antioxidant defense to develop a laboratory technology for effective production of CA SOD by the fungus A. glaucus 363. Our results showed that the cold-stress bioprocessing strategy led to significant increase in enzyme yield. This strategy could be useful for large-scale efficient production of CA SOD. There is no information about the transient temperature downshift application for improvement of SOD yield in biotechnological process. Zhu et al. (2013) reported the positive effect of $\mathrm{NH}_{4}^{+}$and $\mathrm{Mn}^{2+}$ ions on the production of hyperthermostable Mn-SOD in $5 \mathrm{~L}$ bioreactors. This is another bioprocessing strategy that is based on the metal ionsinduced oxidative stress. Our previous studies demonstrated a significant increase in the yield of mesophilic SOD in bioreactor cultures by using both an exposure to $20 \%$ DO level or glucose-feeding technology (Angelova et al. 2001; Krumova et al. 2007). Our study offers a simple and effective procedure for CA SOD purification. The specific activity of the major isoenzyme Cu/Zn-SODII was improved by $150 \%$ while total protein content was decreased by more than $90 \%$. Such specific activity $\left(4000 \mathrm{U} \mathrm{mg}^{-1}\right.$ ) is comparable or even higher than the activity of commercial mesophilic Cu/Zn-SOD.

In addition to the partial gene sequence of $\mathrm{Cu} / \mathrm{Zn}$-SODII, all structural parameters (mass, metal content, N-terminal sequence) relate this major SOD enzyme from $A$. glaucus to homologous SODs specifically found in fungi. For instance, the closest homologue from A. fumigatus Af293 (based on nucleotide and N-terminal sequences) is a small Cu/Zn-SOD (153 amino acid residues, formyl-Met removed) of $15835 \mathrm{Da}$, in perfect agreement with the experimentally determined mass of $\mathrm{Cu} / \mathrm{Zn}$-SODII. By contrast, identification of the high MW $\mathrm{Cu} / \mathrm{Zn}$-SODI from A. glaucus requires further investigations.

The experiments with purified enzyme demonstrated its protective effect on normozoospermic and oligo-asthenoteratozoospermic male partner's semen samples undergoing manipulation procedures for in vitro fertilization (unpublished data).

\section{Conclusion}

Taken together, our results presented an effective laboratory technology for production of CA SOD by the Antarctic fungus Aspergillus glaucus 363. The major isoenzyme $\mathrm{Cu} / \mathrm{Zn}$-SODII is a $15.8 \mathrm{kDa}$ protein, closely related to some homologous SODs from fungi. The purification protocol allows obtaining enzyme with $4000 \mathrm{U} \mathrm{mg}^{-1}$ specific activity that is comparable or even higher than the activity of commercial mesophilic SOD. These findings make A. glaucus 363 worthy of further investigation in larger scale operations. The purified CA enzyme SOD reported in the present work would be boon for application in ART.

\section{Conflict of interest}

The authors declare that they have no conflict of interest.

\section{Informed consent}

All named authors declare that they are agreed to publish this manuscript.

\section{Acknowledgements}

This work was supported by the National Scientific Fund of the Ministry of Education and Science, Bulgaria (DO02-172/ 08), which is greatly acknowledged. Georges Feller was supported by the Fonds de la Recherche Fondamentale et Collective and by the Belgian Program of Interuniversity Attraction Poles (iPros P7/44).

\section{REFERENCES}

Abrashev RI, Pashova SB, Stefanova LN, Vassilev SV, DolashkaAngelova PA, Angelova MB, 2008. Heat-shock-induced oxidative stress and antioxidant response in Aspergillus niger 26. Canadian Journal of Microbiology 54 (12): 977-983.

Agarwal A, Durairajanayagam D, du Plessis SS, 2014. Utility of antioxidants during assisted reproductive techniques: an evidence based review. Reproductive Biology and Endocrinology 12: 112.

Alvarez JG, 2012. Loss of intracellular antioxidant enzyme activity during sperm cryopreservation: effects on sperm function after thawing. In: Parekattil SJ, Agarwal A (eds), Male Infertility 
Contemporary Clinical Approaches, Andrology, ART \& Antioxidants. Springer, New York, Heidelberg, Dordrecht, London, pp. 237-244.

Angelova M, Dolashka-Angelova P, Ivanova E, Serkedjieva J, Slokoska L, Pashova S, Toshkova R, Vassilev S, Simeonov I, Hartmann HJ, Stoeva S, Weser U, Voelter W, 2001. A novel glycosylated $\mathrm{Cu} / \mathrm{Zn}$-containing superoxide dismutase: production and potential therapeutic effect. Microbiology 147: 1641-1650.

Angelova M, Genova L, Pashova S, Slokoska L, Dolashka P, 1996. Effect of cultural conditions on the synthesis of superoxide dismutase by Humicola lutea 110. Journal of Fermentation and Bioengineering 82 (5): 464-468.

Angelova MB, Pashova SB, Spasova B, Vassilev SB, Slokoska LS, 2005. Oxidative stress response of filamentous fungi induced by hydrogen peroxide and paraquat. Mycological Research 109: 150-158.

Atig F, Raffa M, Ben Ali H, Abdelhamid K, Saad A, Ajina M, 2012. Altered antioxidant status and increased lipid per-oxidation in seminal plasma of Tunisian infertile men. International Journal of Biological Sciences 8 (1): 139-149.

Bae J-H, Kwon Mi-Hyun, Kim In-Hwan, Hou Ching T, Kim HakRyul, 2014. Purification and characterization of a cold-active lipase from Pichia lynferdii Y-7723: pH-dependant activity deviation. Biotechnology and Bioprocesses Engineering 19: 851-857.

Baek K-H, Skinner DZ, 2012. Production of reactive oxygen species by freezing stress and the protective roles of antioxidant enzymes in plants. Journal of Agricultural Chemistry and Environment 1: 34-40.

Baez A, Shiloach J, 2013. Escherichia coli avoids high dissolved oxygen stress by activation of SoxRS and manganese-superoxide dismutase. Microbial Cell Factories 12: 12-23.

Bafana A, Dutt S, Kumar S, Ahuja PS, 2011. Superoxide dismutase: an industrial perspective. Critical Reviews in Biotechnology 31 (1): 65-76.

Barghini P, Moscatelli D, Garzillo AMV, Crognale S, Fenice M, 2013. High production of cold-tolerant chitinases on shrimp wastes in bench-top bioreactor by the Antarctic fungus Lecanicillium muscarium CCFEE 5003: bioprocess optimization and characterization of two main enzymes. Enzyme and Microbial Technology 53: 331-338.

Beauchamp C, Fridovich I, 1971. Superoxide dismutase: improved assay and an assay applicable to polyacrylamide gels. Analytical Biochemistry 44 (1): 276-287.

Brenchley JE, 1996. Psychrophilic microorganisms and their coldactive enzymes. Journal of Industrial Microbiology 17: 432-437.

Chary P, Dillon D, Schroederf AL, Natvig DO, 1994. Superoxide dismutase (sod-I) null mutants of Neurospora crussu: oxidative stress sensitivity, spontaneous mutation rate and response to mutagens genetics. Genetics 137: 723-730.

Chattopadhyay MK, Raghu G, Sharma YVRK, Biju AR, Rajasekharan MV, Shivaji S, 2011. Increase in oxidative stress at low temperature in an Antarctic bacterium. Current Microbiology 62: 544-546.

Dolashki A, Abrashev R, Stevanovic S, Stefanova L, Abasid A, Velkova L, Hristova R, Angelova M, Voelter W, Devreese B, Van Beeumen J, Dolashka-Angelova P, 2008. Biochemical properties of $\mathrm{Cu} / \mathrm{Zn}$-superoxide dismutase from fungal strain Aspergillus niger 26. Spectrochimica Acta Part A: Molecular and Biomolecular Spectroscopy 71: 975-983.

Dubois M, Gilles KA, Hamilton JK, Rebers PA, Smith F, 1956. Colorimetric method for determination of sugars and related substances. Analytical Chemistry 28: 350-356.

El Shafey HM, Bahashwan SA, Alghaithy AA, Ghanem S, 2010. Microbial superoxide dismutase enzyme as therapeutic agent and future gene therapy. In: Mendez Vilas (ed.), Current Research, Technology and Education Topics in Applied Microbiology and Microbial Biotechnology. Microbiology Book Series A, vol. 1. Formatex, Spain, pp. 435-443.

Feller G, 2013. Psychrophilic enzymes: from folding to function and biotechnology. Scientifica 2013: 28 Article ID 512840. http: //dx.doi.org/10.1155/2013/512840 Hindawi Publishing Corporation.

Feller G, Gerday C, 2003. Psychrophilic enzymes: hot topics in cold adaptation. Nature Reviews Microbiology 1: 200-208.

Fenice M, Barghini P, Selbmann L, Federici F, 2012. Combined effects of agitation and aeration on the chitinolytic enzymes production by the Antarctic fungus Lecanicillium muscarium CCFEE 5003. Microbial Cell Factories 11: 12. http: //dx.doi.org/10.1186/1475-2859-11-12.

Fernandes L, Bocca AL, Ribero AM, Silva SS, Paes HC, Amaral AC, Polez VLP, Martins NF, Soares CMA, Felipe MSS, 2008. Regulatory networks in the host fungal pathogen interactions. In: San-Blas G, Calderone RA (eds), Pathogenic Fungi: insights in molecular biology. Caister Academic Press, Norfolk, UK, pp. 77-111.

Frealle E, Noel C, Nolard N, Symoens F, Felipe MS, Dei-Cas E, Camus D, Viscogliosi E, Delhaes L, 2006. Manganese superoxide dismutase based phylogeny of pathogenic fungi. Molecular Phylogenetics and Evolution 41: 28-39.

Fridovich I, 1998. Oxygen toxicity: a radical explanation. Journal of Experimental Biology 201: 1203-1209.

Guo FX, Shi-jin E, Liu SA, Chen J, Li DC, 2008. Purification and characterization of a thermostable MnSOD from the thermophilic fungus Chaetomium thermophilum. Mycologia 100: 375-380.

Hou YH, Wang TH, Long H, Zhu HY, 2006. Novel cold-adaptive Penicillium strain FS010 secreting thermo-labile xylanase isolated from Yellow Sea. Acta Biochimica et Biophysica Sinica 38: 142-149.

Jaeger E, Carroll N, Choudhury S, Dunlop A, Towler H, Matheson M, Adamson P, Okhravi N, Lightman S, 2000. Rapid detection and identification of Candida, Aspergillus, and Fusarium species in ocular samples using nested PCR. Journal of Clinical Microbiology 38: 2902-2908.

Joseph B, Ramteke PW, Thomas G, 2008. Cold active microbial lipases: some hot issues and recent developments. Biotechnology Advances 26: 457-470.

Kayihan C, Eyidogan F, Afsar N, Oktem HA, Yucel M, 2012. Cu/Zn superoxide dismutase activity and respective gene expression during cold acclimation and freezing stress in barley cultivars. Biologia Plantarum 56: 693-698.

Kim HR, Kim IH, Hou CT, Kwon KI, Shin BS, 2010. Production of a novel cold-active lipase from Pichia lynferdii Y-7723. Journal of Agricultural and Food Chemistry 58: 1322-1326.

Kostadinova N, Krumova E, Stefanova T, Dishliyska V, Angelova M, 2012. Transient cold shock induces oxidative stress events in Antarctic fungi. In: Lushchak VI, Stoliar O (eds), Oxidative Stress/Book 3. InTech, pp. 75-99.

Krishnan A, Alias SA, Wong CMVL, Pang KL, Convey P, 2011. Extracellular hydrolase enzyme production by soil fungi from King George Island, Antarctica. Polar Biology 34: 1535-1542.

Krumova E, Dolashka-Angelova P, Pashova S, Stefanova L, Beeumen JV, Vassilev S, Angelova M, 2007. Improved production by fed-batch cultivation and some properties of $\mathrm{Cu} / \mathrm{Zn}$ superoxide dismutase from the fungal strain Humicola lutea 103. Enzyme and Microbial Technology 40: 524-532.

Krumova E, Dolashki A, Pashova S, Dolashka-Angelova P, Stevanovic S, Hristova R, Stefanova L, Voelter W, Angelova M, 2008. Unusual location and characterization of $\mathrm{Cu} / \mathrm{Zn}$ containing superoxide dismutase from filamentous fungus Humicola lutea. Archives of Microbiology 189: 121-130.

Laemmli UK, 1970. Cleavage of structural proteins during the assembly of the head of bacteriophage T4. Nature 227: 680-685. 
Lamarre C, LeMay JD, Deslauriers N, Bourbonnais Y, 2001. Candida albicans expresses an unusual cytoplasmic manganesecontaining superoxide dismutase (SOD3 gene product) upon the entry and during the stationary phase. Journal of Biological Chemistry 276: 43784-43791.

Li Q, Harvey LM, McNeil B, 2009. Oxidative stress in industrial fungi. Critical Reviews in Biotechnology 29: 199-213.

Lima OC, Larcher G, Vandeputte P, Lebouil A, Chabasse D, Simoneau P, Bouchara JP, 2007. Molecular cloning and biochemical characterization of a Cu,Zn-superoxide dismutase from Scedosporium apiospermum. Microbes and Infection 9: $558-565$.

Lin YC, Vaseeharan B, Chen JC, 2008. Identification of the extracellular copper-zinc superoxide dismutase (ecCuZnSOD) gene of the mud crab Scylla serrate and its expression following $\beta$ glucan and peptidoglycan injections. Molecular Immunology 45: 1346-1355.

Lowry OH, Rosenbrough HJ, Faar AL, Randall RJ, 1951. Protein measurement with the Folin phenol reagent. Journal of Biological Chemistry 193: 265-275.

Maniatis T, Fritsch E, Sambrook J, 1982. Molecular Cloning: a laboratory manual. Cold Spring Harbor Laboratory Press, Cold Spring Harbor, NY.

Margesin R, Schinner F, Marx JC, Gerday C, 2008. Psychrophiles: from biodiversity to biotechnology. Springer, Berlin.

Merlino A, Krauss IR, Castellano I, De Vendittis E, Rossi B, Conte M, Vergara A, Sica F, 2010. Structure and flexibility in cold-adapted iron superoxide dismutases: the case of the enzyme isolated from Pseudoalteromonas haloplanktis. Journal of Structural Biology 172: 343-352.

Na J, Im H, Lee K, 2011. Expression and purification of recombinant superoxide dismutase (PaSOD) from Psychromonas arctica in Escherichia coli. Bulletin of the Korean Chemical Society 32: 2405-2409.

Nam ES, Ahn JK, 2011. Isolation and characterization of coldadapted bacteria producing lactose hydrolyzing enzyme isolated from soils of Nome area in Alaska. International Research Journal of Microbiology 2 (9): 348-355.

Nevaleinen H, Bradner R, Wadud S, Mohammed S, McRae C, Te'o J, 2012. Enzyme activities and biotechnological applications of cold-active microfungi. In: Anitori RP (ed.), Extremophiles: microbiology and biotechnology. Caister Academic Press, Norfolk, UK, pp. 89-108.

Nierman WC, Pain A, Anderson MJ, Wortman JR, Kim HS, Arroyo J, et al., 2005. Genomic sequence of the pathogenic and allergenic filamentous fungus Aspergillus fumigatus. Nature 438: $1151-1156$.

Onofri S, Selbmann L, de Hoog GS, Grube M, Barreca D, Ruisi S, Zucconi L, 2007. Evolution and adaptation of fungi at boundaries of life. Advances in Space Research 40: 1657-1664.

Pedersen HL, Willassen NP, Leiros I, 2009. The first structure of a cold-adapted superoxide dismutase (SOD): biochemical and structural characterization of iron SOD from Aliivibrio salmonicida. Acta Crystallographica Section F: Structural Biology and Crystallization Communications 65: 84-92.

Raimondi S, Uccelletti D, Amaretti A, Leonardi A, Palleschi C, Rossi M, 2010. Secretion of Kluyveromyces lactis Cu/Zn SOD: strategies for enhanced production. Applied Microbiology and Biotechnology 86: 871-878.
Rowe LA, Degtyareva N, Doetsch PW, 2008. DNA damage-induced reactive oxygen species (ROS) stress response in Saccharomyces cerevisiae. Free Radical Biology and Medicine 45: 1167-1177.

Russell N, 2006. Antarctic microorganisms: coming in from the cold. Culture (Oxoid) 27: 1-4.

Russell NJ, 2003. Psychrophily and resistance to low temperature. In: Gerday C, Glansdorff N (eds), Extremophiles (Life Under Extreme Environmental Condition), Encyclopedia of Life Support Systems (EOLSS). EOLSS Publishers, Oxford Contribution number 6-73-03-00. www.eolss.com.

Singh SM, Singh SK, Yadav LS, Singh PN, Ravindra R, 2012. Filamentous soil fungi from Ny-Ålesund, Spitsbergen, and screening for extracellular enzymes. Arctic 65: 45-55.

Smirnova GV, Zakirova ON, Oktiabr'skil ON, 2001. Role of the antioxidant system in response of Escherichia coli bacteria to cold stress. Mikrobiologiia 70: 55-60 (in Russian).

Somogyi M, 1952. Notes on sugar determination. Journal of Biological Chemistry 195: 19-23.

Tosi S, Kostadinova N, Krumova E, Pashova S, Dishliiska V, Spassova B, Vassilev S, Angelova M, 2010. Antioxidant enzyme activity of filamentous fungi isolated from Livingston Island, Maritime Antarctica. Polar Biology 33: 1227-1237.

Tuteja N, Mishra P, Yadav S, Tajrishi M, Baral S, Sabat SC, 2015. Heterologous expression and biochemical characterization of a highly active and stable chloroplastic CuZn-superoxide dismutase from Pisum sativum. BMC Biotechnology 15: 3.

Xie XQ Li F, Ying SH, Feng MG, 2012. Additive contributions of two manganese-cored superoxide dismutases (MnSODs) to antioxidation, UV tolerance and virulence of Beauveria bassiana. PLoS ONE 7: e30298.

Xie XQ Ying SH, Feng MG, 2010. Characterization of a new Cu/Znsuperoxide dismutase from Beauveria bassiana and two sitedirected mutations crucial to its antioxidation activity without chaperon. Enzyme and Microbial Technology 46: 217-222.

Xu J, Duan X, Yang J, Beeching JR, Zhang P, 2013. Coupled expression of $\mathrm{Cu} / \mathrm{Zn}$-superoxide dismutase and catalase in cassava improves tolerance against cold and drought stresses. Plant Signaling and Behavior 8: e24525.

Youn HD, Kim EJ, Roe JH, Hah YC, Kang SO, 1996. A novel nickelcontaining superoxide dismutase from Streptomyces spp. Journal of Biochemistry 318: 889-896.

Yuan BH, Cai YJ, Liao XR, Yun LH, Zhang F, Zhang D, 2010. Isolation and identification of a cold-adapted lipase producing strain from decayed seeds of Ginkgo biloba L. and characterization of the lipase. African Journal of Biotechnology 9: 2661-2667.

Zheng Z, Jiang YH, Miao JL, Wang QF, Zhang BT, Li GY, 2006. Purification and characterization of a cold-active iron superoxide dismutase from a psychrophilic bacterium, Marinomonas sp. NJ522. Biotechnology Letters 28: 85-88.

Zhu H, Liu J, Qu J, Gao X, Pan T, Cui Z, Zhao X, Lu JR, 2013. Stress fermentation strategies for the production of hyperthermostable superoxide dismutase from Thermus thermophilus HB27: effects of ions. Extremophiles 17: 995-1002.

Zucconi L, Pagano S, Fenice M, Selbmann L, Tosi S, Onofri S, 1996. Growth temperature preferences of fungal strains from Victoria Land, Antarctica. Polar Biology 16: 53-61. 